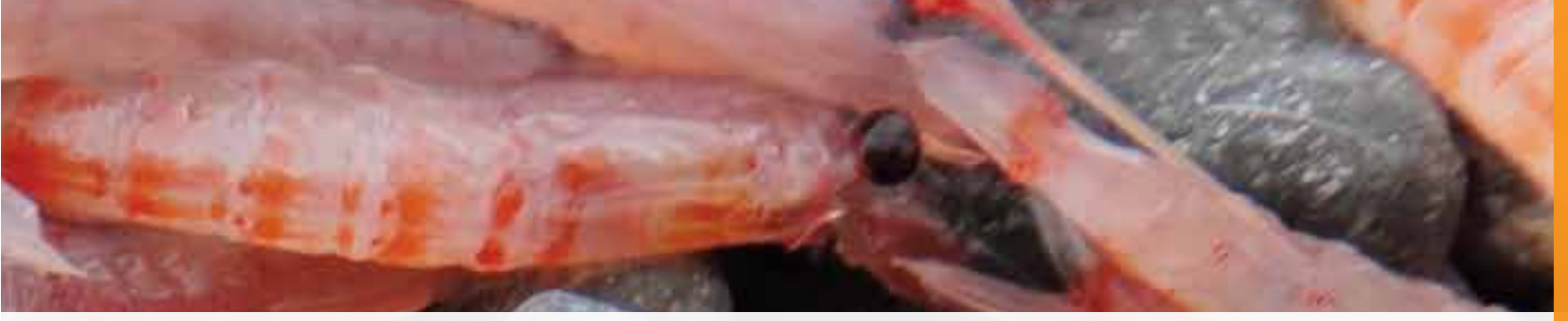

DOI: http://dx.doi.org/10.4322/apa.2015.021

\title{
INFLUENCE OF SEDIMENT QUALITY ON THE BENTHIC COMMUNITIES OF ADMIRALTY BAY, KING GEORGE ISLAND, ANTARCTICA
}

\author{
Thais Navajas Corbisier ${ }^{1 *}$, Márcia Caruso Bícego¹, Sandra Bromberg', Adriana Galindo Dalto², \\ Rubens Cesar Lopes Figueira ${ }^{1}$, Paula Foltran Gheller ${ }^{1}$, Cesar de Castro Martins ${ }^{3}$, \\ Rosalinda Carmela Montone ${ }^{1}$, Cristina Rossi Nakayama ${ }^{4}$, Vivian Helena Pellizari', \\ Mônica Angélica Varella Petti', Satie Taniguchi', Maria Cláudia Yuri Ujikawa \& Helena Passeri Lavrado² \\ 'Departamento de Oceanografia Biológica, Instituto Oceanográfico, Universidade de São Paulo - USP, \\ Praça do Oceanográfico 191, CEP 05508-120, São Paulo, SP, Brazil \\ 2Departamento de Biologia Marinha, Instituto de Biologia, Universidade Federal do Rio de Janeiro - UFRJ, \\ Av. Carlos Chagas Filho 373, CEP 21941-902, Rio de Janeiro, RJ, Brazil \\ ${ }^{3}$ Centro de Estudos do Mar, Universidade Federal do Paraná - UFPR, CP 61, CEP 83255-976, Pontal do Paraná, PR, Brazil \\ ${ }^{4}$ Instituto de Ciências Ambientais, Químicas e Farmacêuticas, Universidade Federal de São Paulo - UNIFESP, \\ Campus Diadema, Rua São Nicolau 210, CEP 09913-030, Diadema, SP, Brazil
}

$$
\text { *e-mail: tncorbis@usp.br }
$$

\begin{abstract}
Marine benthos is widely used in environmental impact studies, especially in coastal areas. A monitoring program of Admiralty Bay has been undertaken since 2008 (National Institute of Science and Technology Antarctic Environmental Research INCT-APA) and, in the summer of 2010, three areas of Martel Inlet and one area of Mackellar Inlet were sampled in order to verify the environmental status of the area in front of the Ferraz Station (CF) in comparison to reference areas. Sediment was collected to analyse their characteristics and quality and to evaluate the meiofauna and macrofauna communities. Meiofauna densities were in the range of those found in previous studies in the bay and did not differ significantly between the sampling sites. Nematodes were the dominant group. On the other hand macrofauna densities were significantly higher in Mackellar Inlet, when comparing with some sites of Martel Inlet. Polychaetes, oligochaetes and bivalves were the dominant macrofauna taxa. Correlation analysis showed different sediment characteristics responsible to explain the abundance of the meiofauna or the macrofauna groups. A change in the meiobenthic and macrobenthic community structure was detected at the site under the sewage outfall influence (CF1: lower density of meiofauna and different taxa composition of macro and meiofauna), suggesting some impact of human activities on the benthic system in front of the Brazilian Station.
\end{abstract}

Keywords: Meiobenthos, Macrobenthos, Sediment Quality, Admiralty Bay

\section{Introduction}

A joint project carried out some years ago (Weber \& Montone, 2006) allowed a preliminary characterization of Admiralty Bay marine environment. The influence of sewage, aliphatic and polycyclic aromatic hydrocarbons was observed only in Martel Inlet near the Brazilian Comandante Ferraz station (EACF) sewage outfall within a distance of $200 \mathrm{~m}$ in the water column and of $400 \mathrm{~m}$ (faecal sterols) and $700 \mathrm{~m}$ (hydrocarbons) in the sediment. Nonetheless, the dispersion of the sewage plume in the shallow coastal zone of Martel Inlet is favoured by the hydrodynamics, especially influenced by the effect of tides. As a result, the contamination in Admiralty Bay is assumed to be punctual and restricted to the proximities of the EACF, especially concerning the sewage outfall (Martins et al., 2005; Bícego et al., 2009).

Although the responses of different groups of organisms to certain types of impact might be expected to differ, there are few studies in which the impact of anthropogenic 
disturbance on more than one component of the biota has been examined directly (Somerfield et al., 1995). The benthic fauna is a component of the marine biota widely used in environmental impact studies, especially in coastal areas.

A monitoring program has been established since 2008 by INCT-APA, and in the summer of 2010, the meiofauna and macrofauna communities, among other sediment variables, were sampled at three areas in Martel Inlet and at one area in Mackellar Inlet in order to verify the environmental status of the area in front of the Brazilian Station (CF) in comparison to reference areas.

\section{Material and Methods}

Sampling was done at 20-30 m depth in four areas of Admiralty Bay, during February 2010 (Figure 1). In each area, sediment of two sites ( $200 \mathrm{~m}$ distant) was collected with a $0.04 \mathrm{~m}^{2}$ mini box-corer in triplicate. From each box corer one meiofauna sample were obtained with a cylindrical corer (area of $4.9 \mathrm{~cm}^{2}$ ), sectioned into 2-cm layers up to $10 \mathrm{~cm}$, and formalin preserved. For macrofauna, three $0.021 \mathrm{~m}^{2}$ corers were obtained and were sectioned in three layers (0-2, 2-6 and 6-10 cm).

In the laboratory, meiofauna samples were washed through $0.5-\mathrm{mm}$ and $0.063-\mathrm{mm}$ meshes and the animals between these sieves were sorted to higher taxonomic groups and counted. In the case of macrofauna, animals retained in $0.5 \mathrm{~mm}$ mesh were sorted into higher taxonomic groups. The first two layers of the sediment $(0$ to $2 \mathrm{~cm}$ ) were sorted up to date for meiofauna and $0-10 \mathrm{~cm}$ for macrofauna. Sediment samples for grain size, organic matter, phytopigments, linear alkylbenzenes (LABs), faecal sterols, total coliforms, hydrocarbons and metals analyses were also obtained from each box corer. The mean fauna density and standard-deviation of the replicates were calculated for each site. Significant differences were calculated using the Kruskal-Wallis test $(p<0.05)$ and the test a posteriori Student-Newman-Keuls. Spearman rank was applied to search for correlation between fauna density and environmental variables.

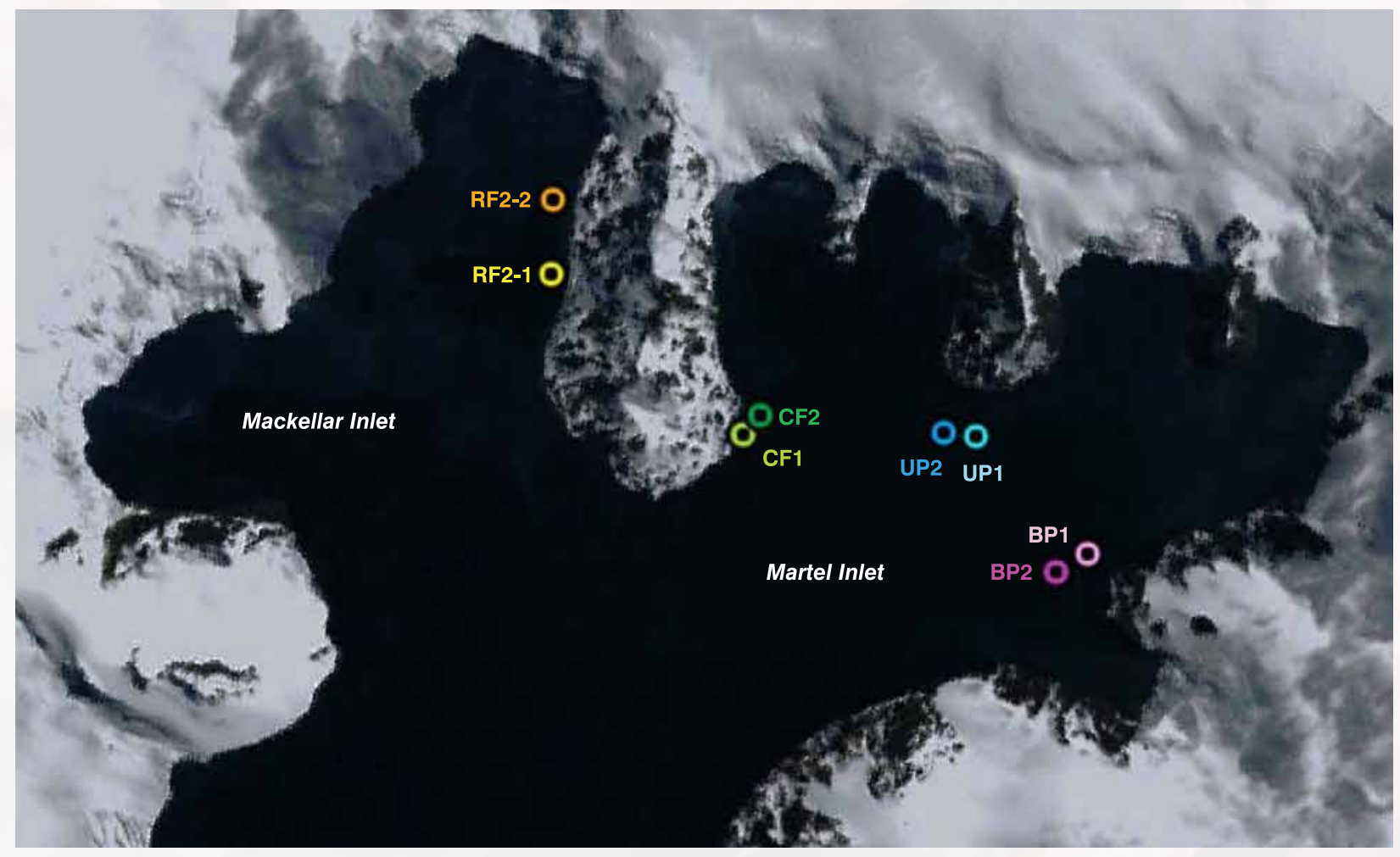

Figure 1. Admiralty Bay and the sampling sites in Martel Inlet (CF, UP, BP) and Mackellar Inlet (RF2) (Google Earth, 2011). CF: Ferraz Station, UP: Ullmann Point, BP: Botany Point and RF2: Refuge 2. 
Table 1. Significant Spearman correlations $(p<0.05)$ between the abundance of the main groups of meiofauna (Nematoda) and macrofauna (Polychaeta and Oligochaeta) and sediment variables.

\begin{tabular}{|c|c|c|c|c|c|c|}
\hline & Coarse sand & Organic matter & $\mathbf{N i}$ & $\mathrm{Zn}$ & coprostanol & epicoprostanol \\
\hline Nematoda & 0,88 & & & 0,71 & & \\
\hline Oligochaeta & & & $-0,71$ & & & $-0,75$ \\
\hline Polychaeta & & $-0,74$ & & & $-0,71$ & $-0,72$ \\
\hline
\end{tabular}
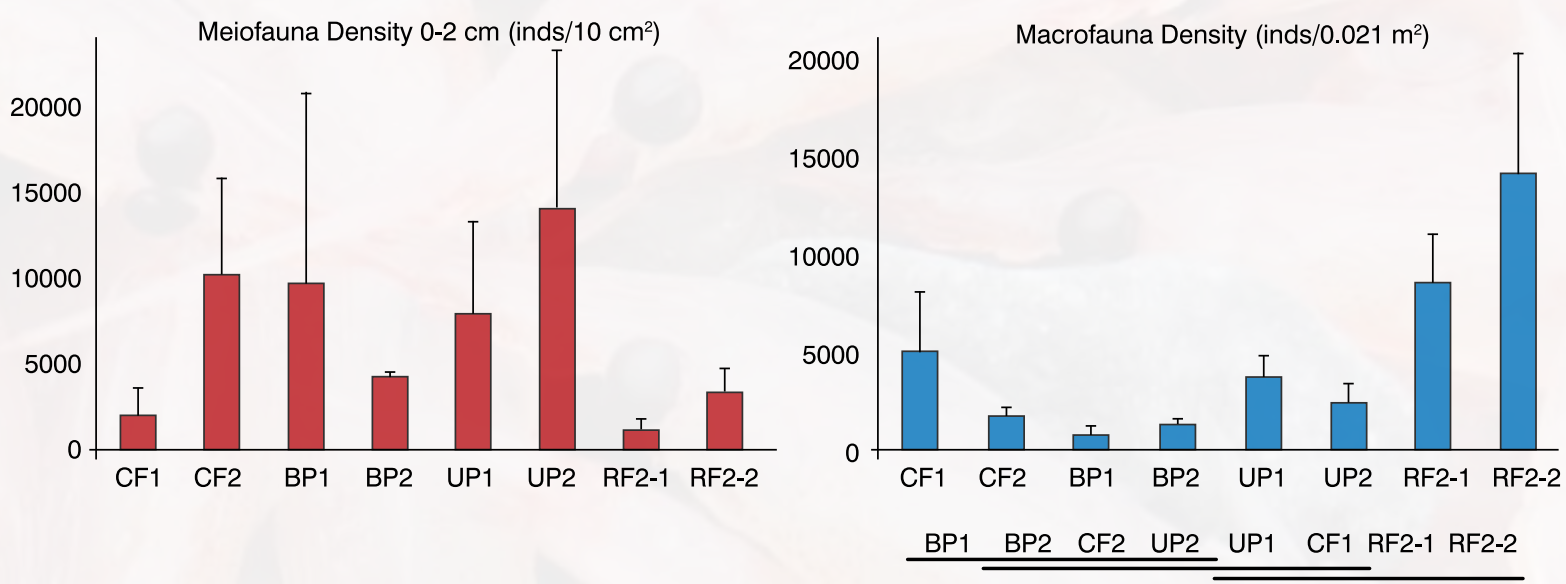

Figure 2. Meio and macrofauna density (mean + standard deviation) at each sampling site. The lines indicate significant differences between the macrofauna densities of each site according the Kruskal-Wallis analysis and the test a posteriori.

\section{Results}

The meiofauna densities ranged from $1261.2 \pm 555.8$ (mean \pm SD) at RF2-1 to $14097.2 \pm 9211.1$ inds. $10 \mathrm{~cm}^{-2}$ at UP2 (Figure 2). Mean densities were lower than 5000 ind. $10 \mathrm{~cm}^{-2}$ at CF1, BP2, RF2-1 and RF2-2, but these were not significantly different from those at the other four points (Kruskal-Wallis analysis, $p=0.06$ ). The macrofauna densities ranged from $74.7 \pm 49.8$ (BP1) to $1423.7 \pm 603.8$ inds.0.021 m-2 at RF2 (Figure 2). The densities of Mackellar Inlet (RF2) were significantly higher than the densities of four sites at Martel Inlet (Kruskal-Wallis analysis, $p=0.005$ ).

Nematodes were dominant, representing between $76.2 \%$ and $98.7 \%$ of the total meiofauna (Figure 3 ). In RF2, polychaetes, nauplii and copepods showed higher representation than at the other points. CF1 presented the highest dominance of nematodes (98.7\%) and the other taxa were nearly absent. In relation to the macrofauna, the annelids (oligochaetes and polychaetes) contributed with more than $50 \%$ at all sites with the exception of CF1, which also has a high contribution of bivalves. Abundance of nematodes was positively correlated to coarse sand and $\mathrm{Zn}$ and macrofauna main groups (polychaetes and oligochaetes) were negatively correlated to two faecal sterols (coprostanol and epicoprostanol). Polychaetes were also negatively correlated to organic matter while oligochaetes to Ni (Table 1).

\section{Discussion and Conclusion}

Meiofauna and macrofauna densities were in the range of those observed in previous studies in Admiralty Bay (Skowronski et al., 1998; Skowronski \& Corbisier, 2002; Weber \& Montone, 2006; Gheller, 2007; Filgueiras et al., 2007). The differences between the sampling sites seem to be more related to natural causes than pollution effects of the Brazilian Station. A higher meiofauna mean density was observed in UP2 (around 14000 ind. $10 \mathrm{~cm}^{-2}$ ), in the 

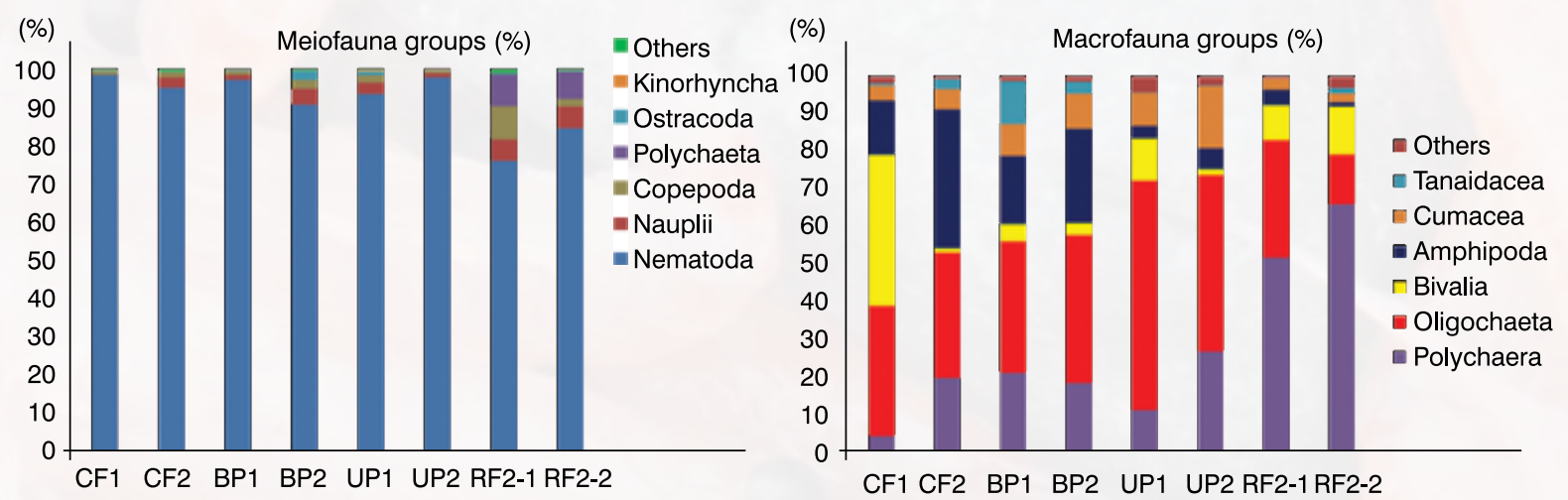

Figure 3. Relative abundance (\%) of meio and macrofauna taxa at each sampling site.

range of densities found in the beginning of the summer of 2004 in CF and BP (Gheller, 2007). CF1, BP2, RF2-1 and RF2-2 had lower meiofauna densities (less than 5000 ind. $10 \mathrm{~cm}^{-2}$ ), especially CF1 and RF2-1 with mean densities of 1963 and 1261 ind. $10 \mathrm{~cm}^{-2}$, respectively. Regarding CF1, under the sewage outfall influence, previous mean densities (Skowronski \& Corbisier, 2002; Gheller, 2007) were two to four times higher than that found in the present study. On the other hand, at CF2, in front of the oil tanks, the mean density of meiofauna was high (around 10000 ind. $10 \mathrm{~cm}^{-2}$ ) and similar to that found in the summer of 2004 (Gheller, 2007). For macrofauna, densities of bivalves $\left(607\right.$ ind.0.021 $\left.\mathrm{m}^{-2}\right)$, polychaetes $\left(70\right.$ ind.0.021 $\left.\mathrm{m}^{-2}\right)$ and oligochaetes (520 ind.0.021 m-2) at Ferraz Station (CF1) fell into the abundance range from previous studies (Weber \& Montone, 2006; Filgueiras et al., 2007) but the relative abundance of bivalves in CF1 found by those authors was lower (ca. 25\%) than present study (ca. 40\%).

The fact that a difference in the meiobenthic and macrobenthic community structure in CF1 (lower meiofauna density and distinct meio and macrofauna composition) and some relationship between benthic abundances and faecal sterols and metals were detected, suggests that some impact due to human activities at this site in front of the Ferraz Station is possible, although of small magnitude and range in the benthic system.

It is important to emphasize that this is a preliminary analysis of the influence of the sediment quality on the meiofauna and macrofauna communities and that until that point we have only identified higher taxonomical groups. The species identification will be extremely necessary to clarify some aspects of these results and will contribute to a better understanding of the real anthropogenic influence in the area.

\section{Acknowledgements}

This work contributes to the National Institute of Science and Technology Antarctic Environmental Research (INCTAPA) that receives scientific and financial support from the National Council for Research and Development (CNPq process: $n^{\circ}$ 574018/2008-5) and Carlos Chagas Research Support Foundation of the State of Rio de Janeiro (FAPERJ $n^{\circ}$ E-16/170.023/2008). The authors also acknowledge the support of the Brazilian Ministries of Science, Technology and Innovation (MCTI), of Environment (MMA) and InterMinistry Commission for Sea Resources (CIRM). 


\section{References}

Bícego, M. C., Zanardi-Lamardo, E., Taniguchi, S., Martins, C. C., Silva, D. A. M., Sasaki, S. T. et al. (2009). Results from a 15-year study on hydrocarbon concentrations in water and sediment from Admiralty Bay, King George Island, Antarctica. Antarctic Science, 21 (3), 209-220. http://dx.doi.org/10.1017/S0954102009001734

Filgueiras, V. L., Campos, L. S., Lavrado, H. P., Frensel, R., \& Pollery, R. C. G. (2007). Vertical distribution of macrobenthic infauna from the shallow sublittoral zone of Admiralty Bay, King George Island, Antarctica. Polar Biology, 30, 1439-1447. http://dx.doi.org/10.1007/s00300-007-0305-z

Gheller, P. F. (2007). A meiofauna e os Nematoda da enseada Martel (Antártica) e seu uso em monitoramento ambiental. (Dissertação de mestrado). Instituto Oceanográfico, Universidade de São Paulo, São Paulo.

Google Earth. (2011). Version 6.0.3. Retrieved from http://www.google.com.br/intl/pt-BR/earth/index.html.

Martins, C. C., Montone, R. C., Gamba, R. C., \& Pellizari, V. H. (2005). Sterols and fecal indicator microorganisms in sediments from Admiralty Bay, Antarctica. Brazilian Journal of Oceanography, 53(1-2), 1-12. http://dx.doi.org/10.1590/ S1679-87592005000100001

Skowronski, R. S. P., Corbisier, T. N., \& Robles, F. R. (1998). Meiofauna along a coastal transect in Admiralty Bay, King George Island (Antarctica). Pesquisa Antártica Brasileira, 3(1), 117-131. http://dx.doi.org/10.1007/s003000100320

Skowronski, R. S. P. \& Corbisier, T. N. (2002). Meiofauna distribution in Martel Inlet, King George Island (Antarctica): sediment features versus food availability. Polar Biology, 25(2), 126-134.

Somerfield, P. J., Rees, H. L., \& Warwick, R. M. (1995). Interrelationships in community structure between shallow-water marine meiofauna and macrofauna in relation to dredgings disposal. Marine Ecology Progress Series, 127, 103-112. http:// dx.doi.org/10.3354/meps127103

Weber, R. R., \& Montone, R. C. (2006). Rede-2: gerenciamento ambiental na Baía do Almirantado, Ilha Rei George, Antártica. Brasília: Ministério do Meio Ambiente/CNPq/SeCIRM/Proantar. 255 p. Relatório final.

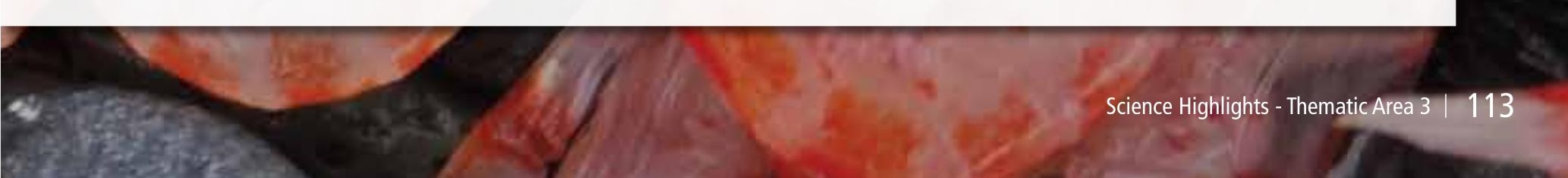

